\title{
Concepts of religion between Asia and Europe - some retrospective
} preliminaries

Uehlinger, Christoph

DOI: https://doi.org/10.1515/asia-2018-0004

Posted at the Zurich Open Repository and Archive, University of Zurich ZORA URL: https://doi.org/10.5167/uzh-152596

Journal Article

Published Version

Originally published at:

Uehlinger, Christoph (2018). Concepts of religion between Asia and Europe - some retrospective preliminaries. Asiatische Studien / Études Asiatiques, 72(1):137-145.

DOI: https://doi.org/10.1515/asia-2018-0004 


\section{Christoph Uehlinger*}

\section{Concepts of Religion between Asia and Europe - Some Retrospective Preliminaries}

https://doi.org/10.1515/asia-2018-0004

The articles by Raji C. Steineck and Christian Novetzke published in this issue of Asiatische Studien/Études Asiatiques go back to contributions offered by the two authors at an international conference entitled "Concepts of Religion between Asia and Europe", held in November 1-3, 2012 under the auspices of the University of Zurich's Priority Research Program “Asia and Europe". ${ }^{1}$ The following remarks, written at the editors' request, are meant to provide some background to questions the two authors address in their papers.

Scholars agree with common sense that 'religion' (from Latin, religio) is a notion of 'Western' (European, Mediterranean, ultimately Roman...) origin (Dubuisson 1998, 2003); that the concept's semantics (meaning) and pragmatics (function) have a long and complicated history with numerous transformations and adaptations from antiquity to present times (Feil 1986-2007; Bergunder 2009; Schlieter 2010); and that the encounter of European colonial powers with non-European societies has had a lasting impact on both sides, since at least the early modern period, on the understanding of 'religion', its many corollaries (such as 'belief', 'ritual', 'worship', 'the sacred' etc.) and its perceived or presumed opposites (such as 'magic', 'superstition', 'science' or 'the secular'). On the one hand, the confessionalization of European Christianities (Beyer 2016) and the encounter with formerly unknown societies, customs and worldviews led European travelers, missionaries, ethnographers and scholars to extend and generalize the concept of 'religion' in an unprecedented way. As a result, 'religion' turned into a Kollektivsingular (R. Koselleck) and a new science based on description, comparison and a particular sense of human history would eventually emerge (Stroumsa 2015). On the other hand, when the concept

$1 \mathrm{http://www.asienundeuropa.uzh.ch/en.html} \mathrm{(the} \mathrm{program} \mathrm{has} \mathrm{come} \mathrm{to} \mathrm{an} \mathrm{end} \mathrm{by} \mathrm{August} \mathrm{31,}$ 2017; the last issue of its bulletin, which can be downloaded at the mentioned URL, offers a retrospective of its activities 2006-2017).

*Corresponding author: Christoph Uehlinger, Department of Religious Studies, University of Zurich, Zürich, Switzerland. E-mail: Christoph.Uehlinger@rws.uzh.ch 
traveled east with missionaries, traders, administrators and explorers, it did so with the power of colonizers but also invested with considerable plausibility and institutional prestige. Together with other, taxonomically related notions (in addition to the above, divinely ordained law, political legitimacy, economic success, later to be followed by such promise-laden concepts as secularism and modernity), it was gradually adopted and appropriated by non-European elites and their societies as well, to become an integral part of the latter's selfunderstanding (Eggert and Hölscher 2013).

One epistemic consequence of these processes has been the conceptualization of 'religion' as a globally diffused social reality (or fait social) and a distinct sphere (or 'system') of social interaction. Another consequence, the inclusion of religion ('religions', 'religious traditions') as a peculiar subject matter for scholarly inquiry, led to the development of Religious Studies as an academic discipline and to countless attempts to arrive at ever more sophisticated definitions of 'religion'. Once it had been isolated conceptually, 'religion' could be classified as a presumed universal. On the other hand, the concept and its institutional stakeholders could and did become objects of radical critique. Whereas 'religion' had formerly been opposed to 'superstition' or 'idolatry' (in the sense of false, non-efficacious and illusionary practice and belief), the concept would since the eighteenth century turn synonymous with 'superstition', or alienated consciousness, for some of its most radical detractors.

During the latter half of the twentieth century, the concept of 'religion' and its academic study have undergone scholarly critique and radical deconstruction. Post-colonial theory has criticized its intimate entanglement with colonialism and imperialism (King 1999, 2010; Chidester 1996, 2014), criticizing the intellectual project labeled 'Comparative Religion' or 'Religious Studies' for its Eurocentrism, Orientalism, and Occidentalism (Fitzgerald 2000). Social anthropologists have drawn attention to religion's ambivalent conceptual and institutional genealogies, stressing the inappropriateness of essentialist claims and assumptions embedded in Western, Christian, or Protestant ideologies (Asad 1993, 2003). The most radical critique has been formulated within the discipline of Religious Studies itself, where a significant number of scholars have engaged in deconstructing the concept, calling for its exclusion from their disciplinary meta-language, if not from scientific inquiry altogether (Fitzgerald 2007) or considering it as nothing else than a category of governance and sovereignty (Stack / Goldenberg / Fitzgerald 2015). Most academic disciplines, however, continue to use the term, whether as a heuristic tool ${ }^{2}$ or because they seem

2 Distinguishing between "unexplained religion" or "religion 1" as the "undisclosed" subject matter of Religious Studies, and "religion 2" (established through discourse analysis and a 
unaffected by postmodern deconstruction. ${ }^{3}$ Moreover, 'religion' has recently developed into a key concept in both public media talk and scholarly discourse for addressing value systems, worldviews and the co-existence of ultimate truth claims in a globalized and culturally pluralized world (Schildermann 2015).

In the context of a research agenda focusing on processes of exchange and adaptation, revision or rejection of concepts travelling between East and West, to critically discuss the concept of 'religion' seemed an almost obvious task to many colleagues involved in the University of Zurich's “Asia and Europe” research cluster. One of our aims was to look behind the screen of superficial consensus according to which 'religion' (both as a concept and as an object) is thought to be an exclusively European invention. The point was neither to deny the pertinence of the concept's critical deconstruction, nor to question its objective alliance with Western colonialism and imperialism over centuries, but to refine historical awareness and enhance social-scientific analysis regarding the concept's career in European and especially in Asian social and intellectual history to this day. Moreover, time seemed ripe (see Gottschalk 2013) to restore balance, so to speak, in our understanding of the concept's history and career and to investigate in more detail how Asian societies and their elites have dealt and continue to deal with the intellectual, cultural and institutional challenges posed to them by both the 'Western' concept of 'religion' and similar concepts of their own breed.

The conference program was divided into four parts. They reflect research interests of the "Asia and Europe" cluster as a whole and of its three sub-fields (Concepts and Taxonomies, Entangled Histories, Norms and Social Order(s).

Part 1: Before Religion ${ }^{4}$ asked how the taxonomic field of various Asian languages and cultural traditions was organized before the encounter with the 'Western' concept of 'religion'. Is it possible (or not) to delineate fields of social and cultural concern in which issues of worldview, ritual practice,

history of 'religion' not as a concept, but as a "name") as the historical subject matter of Religious Studies, Bergunder 2014 has suggested an original way out of the conundrum.

3 To mention an example of the latter from this writer's field of concern, the entry "Religion" in the Reallexikon der Assyriologie (Zgoll 2007) seems unaware of the problem; and a recent overview on "Assyrian religion" (Maul 2017a, b) discusses whether and why it is appropriate to distinguish Assyrian from other Mesopotamian religion, but does not address the more fundamental question whether "religion" is an appropriate category for the study of ancient Assyrian (or for that matter, Mesopotamian) culture and society in the first place. Both articles treat their subject matter quite in the way historically-minded theologians might address Christian religion, following a tradition deeply rooted in nineteenth-century Orientalist scholarship. To be sure, they come from a field which has long considered Mesopotamia to be the cradle of all religion (Bottéro 1998).

4 Nongbri 2013 independently used this same phrase as a book title. 
moral conduct, etc. are semantically clustered in a significant way, possibly distinct from but nevertheless comparable to Western 'religion'? Is it possible (or not) to recognize concepts as well as related practices, norms and orders that might be considered to represent functional equivalents of 'religion', or parts of it? Or is it possible, in turn, to state that certain Asian societies and their languages did not have any pressing need or use for developing such a concept, and that the projection of such a category onto historical data that do not support it may have misled scholars for too long (a point recently made by Barton / Boyarin 2016 with reference to late antique Judaism)? The paper by Raji C. Steineck published below was offered in this part of our conference, alongside with others dealing, e.g., with relevant classifications and discourses in ancient Western Asia (this writer), China before and after the encounter with Buddhism (Max Deeg; see now Deeg / Scheid 2015), medieval India (Angelika Malinar; see ead. 2015), or early modern Mongolia (Karénina Kollmar-Paulenz; see ead. 2007, 2012).

Part 2: Negotiating Religion examined nodes of encounter and entanglement between Asian and Western concepts and taxonomies relating to 'religion'. Among them, missionary encounter since the fifteenth century represent a rather well-investigated area; they fueled information into European ethnography and encyclopedism that would quickly gain status as scholarly, or scientific, knowledge (Stroumsa 2010). We should not only ask how knowledge about Asian customs, practices and beliefs came to inform and enlarge Western concepts of 'religion', but also how Asian elites and societies responded to these encounters. Adopting the Western category and appropriating it to their own needs and concerns would only represent one strategy among others. Exemplifying complex entanglements, James D. Frankel / Stefan Reichmuth (see Reichmuth 2016) addressed the concept of din in between Islamic East-West connections, while Jason A. Josephson argued how the Western concept of 'religion' was reinvented (both as a concept and a discourse) in nineteenth-century Japan as a result of cross-cultural contact and exchange (Josephson 2012; and cf. Isoma'e 2014).

Part 3: Religion defined and delimited addressed processes of conceptual narrowing, which followed the aforementioned developments during the nineteenth century. One may distinguish a unifying, essentializing and normalizing use of 'religion' as a concept referring to an overarching and trans-cultural human reality on the one hand, and the delimitation of specific compounds of tradition as 'religions', on the other. Geoffrey A. Oddie presented the well-known case of Hinduism construed as one, more or less unified religion in India (see Oddie 2006; Gottschalk 2013). Among the 'religions' so delimited, Western scholarly discourse was eager to establish hierarchies based on acclaimed 
paradigms of the time, that is, models of evolution, civilizational progress, social complexity, institutionalization, scholastic sophistication, etc., while at the same distinguishing 'religion' from its presumed opposite, 'the secular'. Asian social elites again adopted this discourse to their own purposes, not least in attempts to inscribe their tradition(s) among the 'world religions' which in the late nineteenth century came to be invoked as major actors of modernity (Masuzawa 2005). In Western, particularly European contexts, the development of normalizing discourses on 'religions' was on the one hand related to increasing secularization and the critical contestation of domestic religion and religious institutions. On the other hand, the conceptual delimitation of 'religion' allowed for the adjective 'religious' (or 'Buddhist', 'Hindu', 'Islamic'...) to be extended into other spheres of meaning: visual art and music, related to any one religion, or particular modes of non-trivial experience would now be classified as 'religious', too, moving religion out of churches and temples to concert halls, exhibitions and salons and foreshadowing the more recent conceptual splits between 'religion' (institutional), 'religiosity' (individual, unbound), and 'spirituality'.

Conceptual histories in Asian contexts have different stories to tell, which have been less studied by Western historians but obviously deserve equal attention (for fine examples, see Nedostup 2013; Schalk 2013; Herrman 2014). One aim of our conference was to highlight common trends that may be observed in various colonial contexts and address regional differences wherever apparent. Christian Novetzke's article published below reflects discussions from this part of the conference. Other contributions included a paper by Lily Kong entitled "Constructing 'religion' in context: The geographical and historical contingencies of religion". Basing herself on empirical data and observations on contemporary Singapore, Kong suggested methodological and theoretical openings far beyond this particular context. That her paper remains unpublished is particularly unfortunate.

Part 4: Religion contested and reclaimed dealt with contemporary discourses on religion in an increasingly polycentric, entangled and globalized world. These discourses seem to be characterized by both centrifugal and centripetal dynamics: On the one hand, 'religions' (reified in the plural) are today often perceived as sources and agents of conflict and intolerance; on the other hand, renewed claims are being heard, from religious stakeholders, public authorities and from scholars of various disciplinary horizons, that religion and religions offer necessary and beneficial contributions to the harmonious development of societies. Former assumptions on secularization and modernity are called into question, and both state bodies and religious agents actively engage in defining how and under what conditions any one religion might be a 'good religion', that is, compatible with the requirements 
of modern, democratic, and pluralistic society. Ironically as it were, disasters provide opportunities for religious stakeholders to bring themselves back to center as meaning-making agents. A fine example of the latter discourse was offered by Katsuhiro Kohata, who described the effects of the 3/11 Fukushima disaster on the concept of religion in contemporary Japan. Last but not least, civil law is claiming increasing power of definition with regard to what may or may not be recognized as 'good religion'. In European and Asian countries alike, such a 'return of religion' into the public sphere and public discourse is, in various, often interrelated ways, observable to the extent that it has become possible and to some extent even plausible to locate a 'religious question' (let alone, a religious quest) in such different contexts as modern India, the People's Republic of China, or Japan. This was a point made during our conference by Yang Fenggang in his paper on "The definition of religion for the social scientific study of religion in China and beyond", and by Volkhard Krech in a closing keynote entitled "Where are the boundaries of religion? Considerations on the emergence of a global religious field and on processes of sacralization".

Interested readers may wonder why this issue of Asiatische Studien/Études Asiatiques does not include more of the papers referred to in this all too brief summary. A variety of reasons can be invoked: First of all, conferences may be experienced by participants as interesting and challenging, and have stirred up lively debates, both critical and constructive, but this alone does not produce a book or coherent thematic journal issue. Our conference, though mainly prepared by members of the "Concepts and taxonomies" research group, was designed as an annual plenary conference of the "Asia and Europe" research program; hence its very broad agenda which, in hindsight, may look somehow over-ambitious, or rather covering too many different fields and disciplines to allow for a properly integrative perspective. Second, several contributors offered content that either had already been published elsewhere or had been committed to other publication projects. Third, some contributions never materialized in full-fledged articles; as a result, it became increasingly difficult to produce a coherent ensemble from the remaining, somewhat fragmentary manuscripts. Last but not least, some of our remaining papers would not pass the threshold of peer reviewing, which, while not diminishing the value these contributions had for our discussions during the conference, is obviously to this journal's credit. I am all the more grateful to Raji C. Steineck and Christian Novetzke for their commitment to the project over several years and for offering their articles both as food for critical reflection and as tokens of collegial friendship. 


\section{References}

Asad, Talal (1993): Genealogies of Religion. Discipline and Reasons of Power in Christianity and Islam. Baltimore and London: Johns Hopkins University Press.

Asad, Talal (2003): Formations of the Secular. Christianity, Islam, Modernity. (Cultural Memory in the Present series). Stanford, CA: Stanford University Press.

Barton, Carlin A. / Boyarin, Daniel (2016): Imagine No Religion: How Modern Abstractions Hide Ancient Realities. New York: Fordham University Press.

Bergunder, Michael (2009): “Religion”. In: Enzyklopädie der Neuzeit, Bd. 10. Stuttgart Weimar: J.B. Metzler, 1048-1062.

Bergunder, Michael (2014): "What is Religion? The Unexplained Subject Matter of Religious Studies". Method and Theory in the Study of Religion 26: 246-286.

Beyer, Peter (2016): "Sensing Religion, Observing Religion, Reconstructing Religion: Contingency and Pluralization in Post-Westphalian Context". Social Compass 63: 234-250.

Bottéro, Jean (1998): La plus vieille religion: En Mésopotamie (coll. Folio Histoire, 82). Paris: Gallimard.

Chidester, David (1996): Savage Systems: Colonialism and Comparative Religion in Southern Africa. Charlottesville, VI: University of Virginia Press.

Chidester, David (2014): Empire of Religion: Imperialism and Comparative Religion. Chicago: University of Chicago Press.

Deeg, Max / Scheid, Bernhard (2015): Religion in China. Major Concepts and Minority Positions. (Beiträge zur Kultur- und Geistesgeschichte Asiens, 85). Wien: Österreichische Akademie der Wissenschaften.

Dubuisson, Daniel (1998): L'Occident et la religion. Mythes, science et idéologie. Bruxelles: Complexe.

Dubuisson, Daniel (2003): The Western Construction of Religion. Myths, Knowledge, and Ideology. Baltimore: Johns Hopkins University Press.

Eggert, Marion / Hölscher, Lucian (eds.) (2013): Religion and Secularity. Transformations and Transfers of Religious Discourses in Europe and Asia. (Dynamics in the History of Religions, 4). Leiden: Brill.

Feil, Ernst (1986-2007): Religio. Die Geschichte eines neuzeitlichen Grundbegriffes vom Frühchristentum bis zur Reformation. 4 vols. Göttingen: Vandenhoeck \& Ruprecht.

Fitzgerald, Timothy (2000): The Ideology of Religious Studies. Oxford: Oxford University Press.

Fitzgerald, Timothy (2007): Discourse on Civility and Barbarity: A Critical History of Religion and Related Categories. Oxford: Oxford University Press, ppb 2010.

Ford Campany, Robert (2003): "On the Very Idea of Religions (in the Modern West and in Early Medieval China)". History of Religions 42: 287-319.

Goossaert, Vincent / Palmer, David A. (2011): The Religious Question in Modern China. Chicago: University of Chicago Press.

Gottschalk, Peter (2013): Religion, Science, and Empire: Classifying Hinduism and Islam in British India. Oxford: Oxford University Press.

Herrman, Adrian (2014): Unterscheidungen der Religion. Analysen zum globalen Religionsdiskurs und dem Problem der Differenzierung von »Religion in buddhistischen Kontexten des 19. und frühen 20. Jahrhunderts (Critical Studies in Religion/ Religionswissenschaft, 10). Göttingen: Vandenhoeck \& Ruprecht. 
Isoma'e, Jun'ichi (2014): Religious Discourse in Modern Japan. Religion, State, and Shintō.

(Dynamics in the History of Religions, 6; Nichibunken Monograph Series, 17).

Leiden: Brill.

Josephson, Jason A. (2012): The Invention of Religion in Japan. Chicago: University of Chicago Press.

King, Richard (1999): Orientalism and Religion. Postcolonial Theory, India and the 'Mystic East'. New York: Routledge.

King, Richard (2010): “Colonialism, Hinduism and the Discourse of Religion”. In: Rethinking Religion in India. The Colonial Construction of Hinduism. Edited by E. Bloch, M. Keppens and R. Hegde (Routledge South Asian Religion Series). London and New York: Routledge, 95-113.

Kollmar-Paulenz, Karénina (2007): Zur Ausdifferenzierung eines autonomen Bereichs Religion in asiatischen Gesellschaften des 17. und 18. Jahrhunderts: Das Beispiel der Mongolen (Akademievorträge, H. XVI). Bern: Schweizerische Akademie der Geistes- und Sozialwissenschaften.

Kollmar-Paulenz, Karénina (2012): “Außereuropäische Religionsbegriffe”. In:

Religionswissenschaft. Edited by M. Stausberg (De Gruyter Studium). Berlin: Walter de Gruyter, 81-94.

Malinar, Angelika (2015): “Religion”. In: Key Concepts in Modern Indian Studies. Edited by G. Dharampal-Frick et al. Oxford: Oxford University Press, 289-297.

Masuzawa, Tomoko (2005): The Invention of World Religions. Or, How European Universalism Was Preserved in the Language of Pluralism. Chicago: University of Chicago Press.

Maul, Stefan M. (2017a): "Die assyrische Religion”. In: Zwischen Karawane und Orientexpress. Streifzüge durch Jahrtausende orientalischer Geschichte und Kultur. Edited by J. Giessauf

(FS Hannes Galter; Alter Orient und Altes Testament, 434). Münster: Ugarit-Verlag, 211-240.

Maul, Stefan M. (2017b): “Assyrian Religion”. In: A Companion to Assyria. Edited by E. Frahm (Blackwell Companions to the Ancient World). Oxford: Wiley-Blackwell, 336-358.

Nedostup, Rebecca (2013): "The Transformation of the Concept of Religion in Chinese Modernity". In: Religious Diversity in Chinese Thought. Edited by P. Schmidt-Leukel and J. Gentz. New York: Palgrave MacMillan, 157-170.

Nongbri, Brent (2013): Before Religion: A History of a Modern Concept. New Haven, CT: Yale University Press.

Oddie, Geoffrey A. (2006): Imagined Hinduism: British Protestant Missionary Constructions of Hinduism, 1793-1900. New Delhi: Sage Publications.

Reichmuth, Stefan (2016): "The Arabic Concept of Dīn and Islamic Religious Sciences in the 18th Century: The Case of Murtaḍā al-Zabīdī (d. 1791)". Oriens 42: 94-115.

Schalk, Peter (ed.) (2013): Religion in Asien? Studien zur Anwendbarkeit des Religionsbegriffs. (Acta Universitatis Upsaliensis. Historia Religionum, 32). Uppsala: Uppsala Universitet.

Schildermann, Hans (ed.) (2015): The Concept of Religion. Defining and Measuring Contemporary Beliefs and Practices. Leiden: Brill.

Schlieter, Jens (2010): Was ist Religion? Texte von Cicero bis Luhmann. (Reclam's UniversalBibliothek, 18785). Stuttgart: Philipp Reclam jun. 
Stack, Trevor / Goldenberg, Naomi R. / Fitzgerald, Timothy (eds.) (2015): Religion as a Category of Governance and Sovereignty. (Supplements to Method \& Theory in the Study of Religion, 3). Leiden: Brill.

Stroumsa, Guy G. (2010): A New Science: The Discovery of Religion in the Age of Reason. Cambridge, MA: Harvard University Press.

Stroumsa, Guy G. (2015): “The Scholarly Discovery of Religion in Early Modern Times”. In: The Cambridge History of the World. Vol. VI. Edited by M. E. Wiesner-Hanks and S. Subrahmanyam. Cambridge: Cambridge University Press, 313-333.

Zgoll, Annette (2007): “Religion. A. In Mesopotamien”. In: Reallexikon der Assyriologie und der vordersiatischen Archäologie. Band 11. Berlin: Walter de Gruyter, 323-333. 